\title{
Distribution of allelic and genotypic frequencies of NAT2 and CYP2E1 variants in Moroccan population
}

\author{
Soukaina Guaoua ${ }^{1 *}$, Ilham Ratbi ${ }^{1}$, Fatima Zahra Laarabi ${ }^{2}$, Siham Chafai Elalaoui ${ }^{1,2}$, Imane Cherkaoui Jaouad ${ }^{1,2}$,
} Amina Barkat ${ }^{3}$ and Abdelaziz Sefiani, ${ }^{1,2}$

\begin{abstract}
Background: Several pathogenesis and genetic factors influence predisposition to antituberculosis drug-induced hepatotoxicity (ATDH) especially for isoniazid (INH). However, the major susceptibility genes for ATDH are $\mathrm{N}$-acetyltransferase 2 (NAT2) and cytochrome P450 2E1 (CYP2E1). NAT2 gene determines the individual's acetylator status (fast, intermediate or slow) to metabolize drugs and xenobiotics, while CYP2E1 C1/c1 genotype carriers had an increased risk of ATDH.

Polymorphisms of the NAT2 and CYP2E1 genes vary remarkably among the populations of different ethnic origins. The aim of this study was to determine, for the first time, the frequency of slow acetylators in Moroccan population by genotyping of NAT2 gene variants and determining the genotype $\mathrm{Cl} / \mathrm{C} 1$ for CYP2E1 gene, in order to predict adverse effects of Tuberculosis treatment, particularly hepatotoxicity.
\end{abstract}

Results: The frequencies of specific NAT2 alleles were 53\%, 25\%, 2\% and 4\% for NAT2*5, NAT2*6, NAT2*7 and NAT2*14 respectively among 163 Moroccan studied group. Genotyping of CYP2E1 gene, by real-time polymerase chain reaction using TaqMan probes, revealed frequencies of $98.5 \%$ for $\mathrm{c} 1 / \mathrm{c} 1$ and 1.5\% for $\mathrm{c} 1 / \mathrm{c} 2$ among 130 Moroccan studied group.

Conclusion: The most prevalent genotypes of NAT2 gene in Moroccans are those which encode slow acetylation phenotype (72.39\%), leading to a high risk of ATDH. Most Moroccans are homozygous for c1 allele of CYP2E1 gene which aggravates hepatotoxicity in slow acetylators.

This genetic background should be taken into account in determining the minimum dose of INH needed to treat Moroccan TB patients, in order to decrease adverse effects.

Keywords: Tuberculosis, CYP2E1 gene, NAT2 gene, Polymorphism, Acetylators, Adverse effects, Moroccans

\section{Background}

Pharmacogenetics refers to genetic differences in metabolic pathways which can affect individual responses to drugs, both in terms of therapeutic effect as well as adverse effects. Pharmacogenetics is generally regarded as the study or clinical testing of genetic variation that gives rise to differing responses to drugs. Its purpose is to optimize the therapeutic decisions based on the genome of the individual and the target molecule. Medicines are

\footnotetext{
*Correspondence: soukainaguaoua@gmail.com

'Centre de génomique humaine, Faculté de médecine et de pharmacie, Université Mohammed V, Rabat, Morocco

Full list of author information is available at the end of the article
}

developed and used together with pharmacodiagnosis tools to achieve desired drug efficacy and safety.

Tuberculosis (TB) is an infectious disease caused by the Mycobacterium tuberculosis. TB remains to date one of the major public health problems in the world, with 8.6 million of incident cases, 12.0 million prevalent cases and 1.3 million deaths in 2012 [1]. In Morocco, 27,429 new cases of TB were reported in 2012, an incidence of 83 new cases per 100,000 inhabitants, according to the epidemiological services of the Moroccan Ministry of Health (Unpublished data).

The main drugs to treat TB are isoniazid (INH), rifampicin (RMP) and pyrazinamide (PZA), ethambutol (EMB) and/or streptomycin used in combination for 6 months or 
more [2]. Tuberculosis treatment cause adverse drug reactions (ADRs), including hepatitis, gastrointestinal intolerance, kidney failure, cutaneous and hematological reactions, which can lead to therapy discontinuation or more serious morbidity and mortality [3]. Among firstline anti-TB drugs, INH is the most effective but also the one that can easily cause hepatotoxicity.

The incidence of anti-tuberculosis drug-induced hepatotoxicity ranges from $1 \%$ to $36 \%$ [3-6]. Genetic factors have been reported as a risk for hepatotoxicity [7-10]. These factors were attributed to genetic variability in arylamine $\mathrm{N}$-acetyltransferase2 (NAT2) gene, a cytosolic phase II conjugation enzyme primarily responsible for the deactivation of INH [7-11]. INH is metabolized to acetylisoniazid via hepatic NAT2 [12]. On the other hand, acetylisoniazid is hydrolyzed to acetylhydrazine, which is oxidized by cytochrome P450 2E1 (CYP2E1) to form some hepatotoxic intermediates $[13,14]$. Disposal of acetylhydrazine also depends on further acetylation by NAT2 to form a non-toxic metabolite, diacetylhydrazine $[15,16]$.

NAT2 gene on $8 \mathrm{p} 22$ is a key human enzyme in drug detoxification and elimination. Variants in NAT2 gene affect the activity of anti-tuberculosis drugs and result in three different phenotypes: rapid (RA), intermediate (IA) and slow acetylators (SA). Most SNPs reported to date are found within the $873 \mathrm{bp}$ intronless coding region of NAT2 gene. Among the seven most common SNPs, four result in amino acid changes leading to a significant decrease in acetylation capacity and are associated to slow acetylator phenotype rs1801280 (c.341 T > C; NAT2*5), rs1799930 (c.590G > A; NAT2*6), rs1799931 (c.857 G > A; NAT2*7), and rs1801279 (c.191G > A; NAT2*14) [17,18]. The three others rs1041983 (c.282C > T; NAT2*13A), rs1799929 (c.481C > T; NAT2*11A), rs1208 (c.803A > G; NAT2*12A) are synonymous SNPs or do not alter the phenotype $[17,18]$. They have been identified as fast alleles $[19,20]$.

$N A T 2 * 4$ is considered as the reference allele in the case of absence of all the known SNPs, and is designated as a fast allele $[19,20]$. A heterozygous compound genotype (NAT2 $* 4 / * 14$ or NAT2 $* 4 / * 5$ or NAT2 $* 4 / * 6$ or NAT2 $24 / * 7$ ) is considered as intermediate acetylator. The pharmacogenetic interest of these data lies in adjusting the dose of isoniazid based on genotype and phenotype found in the patient in order to prevent hepatotoxicity [21].

In humans, the CYP2E1 enzyme is encoded by the CYP2E1 gene on 10q24.3qter [22]. Various polymorphisms have been identified in the CYP2E1 gene, of which the CYP2E1 RsaI/PstI polymorphism (rs2031920; -1053 C > T (Rsa $1 \mathrm{c} 1>\mathrm{c} 2)$ ) in its 50-flanking region may affect the activity or inductibility of the enzyme $[23,24]$.
Polymorphisms of the NAT2 and CYP2E1 genes vary remarkably among the populations of different ethnic origins. Acetylators phenotypes in Moroccan population were previously reported to have a higher frequency of phenotypic slow acetylators [25].

The aim of this study was to determine the distribution of allelic and genotypic frequencies of NAT2 and CYP2E1 variants in Moroccan controls in order to estimate the prevalence of slow acetylators among Moroccans, who are facing the risk to develop hepatotoxicity after TB treatment.

\section{Results}

In this study we identified twelve different genotypes for NAT2 gene. The most of them encode for the slow acetylator phenotype. Genotypes of the four variants of NAT2 gene and their corresponding phenotypic profiles are presented in Table 1 . With regard to phenotype, the results show that $72.39 \%$ [95\% CI 65.39-79.39] of the studied group were SA, 21.48\% [95\% CI 15.04-27.91] were IA and $6.13 \%$ [95\% CI 2.38-9.88] were RA. For the four variants NAT2*5, NAT2*6, NAT2*7 and NAT2*14 of NAT2 gene, the allelic frequencies in the studied group were 53\% [95\% CI 47-58], 25\% [95\% CI 20-29], 2\% [95\% CI 1-3] and 4\% [95\% CI 2-6], respectively (Table 2). NAT2 alleles frequencies of Moroccans compared with other populations are shown in Table 2.

The allelic and genotypic distribution of the rs2031920 variant of CYP2E1 in the studied group is reported in Table 3 . The $\mathrm{c} 2 / \mathrm{c} 2$ genotype was not found in the studied group. It seems that the majority of Moroccans are carriers of $\mathrm{c} 1 / \mathrm{c} 1$ genotype with a frequency of $98.5 \%$ [95\% CI 96-100]. CYP2E1 genotypic frequencies of Moroccans compared with different populations of the world are shown in Table 4.

\begin{tabular}{|c|c|c|}
\hline Genotype & Genotype frequency & Phenotype \\
\hline NAT2*4/*4 & 0.0613 & RA \\
\hline NAT2*4/*5 & 0.1166 & $\mathrm{IA}$ \\
\hline NAT $2 * 4 /{ }^{*} 6$ & 0.0859 & IA \\
\hline NAT2* $4 / * 14$ & 0.0123 & IA \\
\hline NAT2*5/*5 & 0.3313 & SA \\
\hline NAT2*5/*6 & 0.2209 & SA \\
\hline NAT $2 * 5 / * 7$ & 0.0184 & SA \\
\hline NAT2*5/*14 & 0.0368 & SA \\
\hline NAT2* $6 /{ }^{*} 6$ & 0.0797 & SA \\
\hline NAT2*6/*7 & 0.0184 & SA \\
\hline NAT2*6/*14 & 0.0123 & SA \\
\hline NAT2*14/*14 & 0.0061 & SA \\
\hline
\end{tabular}


Table 2 NAT2 alleles frequencies among Moroccan population and other ethnic groups

\begin{tabular}{lccccc}
\hline Ethnic groups & $\mathbf{n}$ & NAT2*5 & NAT2*6 & NAT2*7 & NAT2*14 \\
\hline Caucasians [26] & 3531 & 0.46 & 0.285 & 0.029 & 0.013 \\
Germanians [27] & 844 & 0.425 & 0.278 & 0.019 & 0.001 \\
Americans [27] & 387 & 0.437 & 0.266 & 0.132 & 0.001 \\
Southern Korean [27] & 288 & 0.01 & 0.224 & 0.006 & 0.00 \\
Spanish [27] & 258 & 0.47 & 0.25 & 0.021 & 0.004 \\
Southern Brazil [28] & 254 & 0.289 & 0.104 & 0.028 & 0.014 \\
Egyptian [29] & 199 & 0.497 & 0.26 & 0.08 & - \\
Argentine [30] & 185 & 0.37 & 0.256 & 0.04 & 0.013 \\
Omanians [31] & 127 & 0.44 & 0.27 & 0.00 & 0.00 \\
Senegalians [27] & 101 & 0.322 & 0.188 & 0.15 & 0.084 \\
Tunisians [32] & 100 & 0.315 & 0.175 & 0.067 & 0.05 \\
South Africa [27] & 97 & 0.361 & 0.17 & 0.103 \\
Japanese [33] & 79 & 0.019 & 0.23 & 0.03 & - \\
Indians [33] & 61 & 0.33 & 0.38 & 0.02 &
\end{tabular}

n: sample size.

\section{Discussion}

This results show that slow acetylators are the most frequent in our Moroccan population, and the NAT2*5 allele is the most represented. Comparing the allele frequencies of the four NAT2 variants reported in Table 2, the distribution pattern of NAT2*14 in Tunisian and NAT2 $\%$, NAT2 $* 7$ in Caucasians populations did not vary significantly from our population $(\mathrm{p}>0.05)$. On the other side, the allelic distribution in our population is different from other populations as Tunisians for the three alleles NAT2*5, NAT2 $* 6$ and NAT2*7 and from Caucasians for two alleles NAT2* 5 and NAT2*14, this difference is statistically significant $(\mathrm{p}<0.05)[26,32]$.

This difference with Tunisian neighbors could be explained by the origins of the Moroccan and Tunisian populations. Since about 8000 years ago native Berbers have been the major population group in all the North African regions, but through the centuries, Berbers have mixed differently with many other ethnic groups, Phoenicians, Carthaginians, Romans, Vandals, Byzantines, and Arabs whereas Ottoman rule reached Tunisia only $[41,42]$. Other explanation of the difference between our population and Tunisians could be a selection bias, and the limited size of their group controls.

Table 3 Allele and genotype frequencies of rs2031920 polymorphism in Moroccan controls

\begin{tabular}{lcclcc}
\hline & \multicolumn{3}{c}{ Allele } & & \multicolumn{2}{c}{ Genotype } \\
\cline { 2 - 3 } \cline { 6 - 6 } & $\mathbf{c 1}$ & $\mathbf{c 2}$ & & $\mathbf{c 1 / c 1}$ & $\mathbf{c 1 / \mathbf { c 2 }}$ \\
\hline Frequency & 0.992 & 0.008 & & 0.985 & 0.015 \\
\hline
\end{tabular}

Studies have shown variation in the distribution of NAT2 alleles among different populations, where four major groups could be distinguished according to the frequency of $N A T 2 * 5$ and NAT2*6 alleles and according to the presence of NAT2*7 and NAT2*14 alleles. NAT2*5 allele is the most common among Caucasian, Egyptian and Omanian populations as in our population [26,29,31], while Asians such as South Korean and Japanese populations, have less $N A T 2 * 5$ and more NAT2*7 $[26,27,33]$. NAT2 6 variant is at the second position in our population similarly to Caucasians [26]. NAT2*14 allele, at the third position in our population, is rare in Caucasians and absent in Omanian and Southern Korea populations $[26,27,31]$.

Junichi Azuma et al. 2012 [21], proposed in their recent study about NAT2 genotypes and impact on doses of INH to increase the recommended dose of $5 \mathrm{mg} / \mathrm{kg}$ by the World Health Organization (WHO) to $7.5 \mathrm{mg} / \mathrm{kg}$ in rapid acetylators, maintain it in intermediate acetylators, and reduce it to $2.5 \mathrm{mg} / \mathrm{kg}$ in slow acetylators. As Moroccans are mainly slow acetylators, we propose according to our results to reduce the dose of INH in TB patients carrying slow acetylators genotypes, in order to prevent hepatotoxicity and to decrease the cost of managing adverse events.

For the polymorphism rs2031920 of the CYP2E1 gene, our studied group consisted of 130 controls, originated from different regions of Morocco. From our results, it appears that there is a high frequency of $\mathrm{c} 1 / \mathrm{c} 1$ genotype in Moroccan population (Table 3), which aggravates hepatotoxicity in slow acetylators patients under TB treatment. In Table 4, we compared our results with 
Table 4 Genotypic frequencies of rs2031920 polymorphism of CYP2E1 gene in different populations of the world

\begin{tabular}{lccccccccccc}
\hline & $\begin{array}{c}\text { Turkish } \\
{[\text { [3] }}\end{array}$ & $\begin{array}{c}\text { Germanians } \\
\text { [35] }\end{array}$ & $\begin{array}{c}\text { Taiwanese } \\
\text { [9] }\end{array}$ & $\begin{array}{c}\text { Serbians } \\
{[\text { [36] }}\end{array}$ & $\begin{array}{c}\text { French } \\
{[\text { [37] }}\end{array}$ & $\begin{array}{c}\text { English } \\
{[\text { [38] }}\end{array}$ & $\begin{array}{c}\text { Brazilians } \\
{[\text { [28] }}\end{array}$ & $\begin{array}{c}\text { Chinese } \\
{[\text { 26] }}\end{array}$ & $\begin{array}{c}\text { Indians } \\
\text { [39] }\end{array}$ & $\begin{array}{c}\text { Spanish } \\
\text { [40] }\end{array}$ & $\begin{array}{c}\text { Moroccans } \\
\text { (This study) }\end{array}$ \\
\hline $\mathrm{C} 1 / \mathrm{c} 1$ & 0.947 & 0.949 & 0.55 & 0.904 & 0.916 & 0.968 & 0.908 & 0.598 & 0.98 & 0.879 & 0.985 \\
$\mathrm{C} 1 / \mathrm{c} 2$ & 0.053 & 0.044 & 0.401 & 0.09 & 0.047 & 0.032 & 0.592 & 0.374 & 0.02 & 0.121 & 0.015 \\
$\mathrm{C} 2 / \mathrm{c} 2$ & 0.000 & 0.007 & 0.048 & 0.006 & 0.000 & 0.000 & 0.000 & 0.028 & 0.00 & 0.000 & 0.000 \\
$\mathbf{n}$ & 302 & 297 & 269 & 177 & 172 & 155 & 141 & 107 & 100 & 58 & 130 \\
\hline
\end{tabular}

n: sample size.

those of other reported populations. The frequencies of $\mathrm{c} 1 / \mathrm{c} 1, \mathrm{c} 1 / \mathrm{c} 2$ and $\mathrm{c} 2 / \mathrm{c} 2$ genotypes in Moroccans were close to those found in Caucasians $[35,37,38]$.

\section{Conclusion}

In conclusion, this preliminary study shows that more than $70 \%$ of Moroccan subjects are carriers of NAT2*5, NAT2 6 , NAT2 $* 7$ and NAT2*14 genotypes compatible with a slow acetylators status, and therefore, they are sensitive to lower doses of TB treatment. We should take into account this high prevalence of slow acetylators in order to decrease adverse effects, especially knowing that a vast majority of Moroccans are also homozygous for the c1 allele of CYP2E1 gene, which aggravates hepatotoxicity.

\section{Methods \\ Studied population}

Blood samples were collected from umbilical cords of 163 unrelated newborns. They originated from different regions of Morocco and the Moroccan origin of their parents and grandparents was confirmed. Informed consent for DNA analysis was obtained from the parents. Ethics approval was obtained from the local committee of National institute of Hygiene in Rabat for this study.

\section{Genotyping protocol}

Genomic DNA was extracted from three $\mathrm{mL}$ of blood using the salting-out method [43]. The quality and quantity of the DNA were controlled by A260/A280 using a Nanodrop spectrophotometer (2000/2000c Nanodrop; Fisher Scientific, Wilmington, DE, USA) and aliquots (50-100 $\mu \mathrm{L})$ of packed blood cells were stored at $4{ }^{\circ} \mathrm{C}$ until analyses. One hundred nanograms of extracted DNA was amplified in a final volume of $20 \mu \mathrm{L}$. Real time PCR mixture contained $10 \mu \mathrm{L}$ of Master Mix (2X, TaqMan Genotyping Master Mix, Applied Biosystems), $0.5 \mu \mathrm{L}$ of a specific probe (40 X, TaqMan, Applied Biosystems). The amplification protocol involves three steps, PCR which includes activation of Taq polymerase heating at $95^{\circ} \mathrm{C}$ for 10 minutes, followed by 40 cycles of amplification of 75 seconds each cycle (DNA denaturation for 15 seconds at $92^{\circ} \mathrm{C}$, Hybridization for 1 minute at $60^{\circ} \mathrm{C}$ ) and ends with Post-PCR Read at $60^{\circ} \mathrm{C}$ for 1 minute.

We genotyped 163 DNA samples for the four SNPs with strongest impact on the acetylation profile: rs1801280 (c.341 T > C; NAT2*5), rs1799930 (c.590G > A; NAT2*6), rs1799931 (c.857 G>A; NAT2*7), and rs1801279 (c.191G > A; NAT2*14) polymorphisms of NAT2 gene and 130 DNA samples for the rs2031920 polymorphism of CYP2E1 gene.

Genotyping of SNPs of both genes was performed with an allele-specific probe of SNP using allele-specific realtime polymerase chain reaction (StepOne Real-Time PCR System; Applied Biosystems7500, Foster City, CA, USA) using TaqMan (Applied Biosystems, Warrington, UK) probes. This method combines PCR and mutation detection in a single step. A hybridization probe is cleaved by the 5' nuclease activity of Taq DNA polymerase only if the specific sequence is successfully amplified. Two TaqMan probes are used, one for each allele. TaqMan probes consist of a 18-22 bp oligonucleotide probe which is labeled with a reporter fluorophore at the 5 ' end and a quencher fluorophore at the 3' end. Allelic discrimination was obtained by the post-PCR read of fluorescence intensity.

For the CYP2E1 polymorphisme the primers sequences were from assays-by-designs ${ }^{\mathrm{SM}}$ of the manufacturer's (Applied Biosystems). Alleles of rs2031920 were assessed using primers rs2031920_F: TGACTTTTA TTTTCTTCATTTCTCATCATATTTTCTATTATACAT and rs2031920_R: GTTTTTCATTCTGTCTTCTAACT GGCAATAT and the Taqman probes rs2031920_V: VIC AGGTTGCAATTTTGTACTTT and rs2031920_F: FAM GTTGCAATTTTATACTTT (SNP position highlighted).

For the four polymorphisms of NAT2 gene, the primers sequences were from Drug metabolism genotyping assay of the manufacturer's (Applied Biosystems) which reference is ( $\mathrm{p} / \mathrm{n}$ 4362038).

Genotype frequencies in our population were calculated in accordance with the Hardy-Weinberg equilibrium. Intervals confidence $95 \%$ were calculated for phenotypic genotypic and allelic frequencies.

\section{Statistical analysis}

Statistical analysis was performed using the SPSS (Statistical Package for the Social Sciences) version 17.0 for 
windows. The chi-square test was used to determine whether there is a significant difference between the expected frequencies and the observed frequencies relative to NAT2 gene distribution in the studied group versus other populations. Statistical significance was assumed at the $\mathrm{p}<0.05$.

\section{Abbreviations}

ATDH: Antituberculosis drug-induced hepatotoxicity; INH: Isoniazid; NAT2: N-acetyltransferase 2; CYP2E1: Cytochrome P450 2E1; TB: Tuberculosis; INH: Isoniazid; RMP: Rifampicin; PZA: Pyrazinamide; EMB: Ethambutol; ADRs: Adverse drug reactions; RA: Rapid acetylator; IA: Intermediate acetylator; SA: Slow acetylator; WHO: World Health Organization; SPSS: Statistical package for the social sciences; n: Sample size.

\section{Competing interests}

The authors declare that they have no competing interests.

\section{Authors' contributions}

SG molecular study, redaction of the manuscript, statistic study. IR analysis of data, redaction of the manuscript. FZL contribution to molecular study. SCEA preparation of the controls data. CJI contribution to statistic study. $A B$ recruitment of controls. AS conception of the study, analysis of data. All authors read and approved the final manuscript.

\section{Acknowledgments}

The authors would like to thank all the staff of the Medical Genetics Department of the National Institute of Health for their support.

The authors would like to thank also Dr Jauad El Kharraz for his careful reading of the paper.

\section{Author details}

${ }^{1}$ Centre de génomique humaine, Faculté de médecine et de pharmacie, Université Mohammed $V$, Rabat, Morocco. ${ }^{2}$ Département de génétique médicale, Institut National d'Hygiène, Rabat, Morocco. ${ }^{3}$ Centre National de Référence en Néonatologie et en Nutrition, Rabat, Morocco.

Received: 20 May 2014 Accepted: 18 December 2014

Published online: 29 December 2014

\section{References}

1. Data WOHWLC-i-P: Global tuberculosis report 2013. In Book Global tuberculosis report, 2013. Edited by Global tuberculosis report 2013. Switzerland: World Health Organization (WHO); 2013.

2. WHO: Anti-Tuberculosis Drug Resistance in the World: The WHO/IUATLD Global Project on Anti-Tuberculosis Drug Resistance Surveillance Report No. 3. Geneva: WHO; 2004.

3. Forget EJ, Menzies D: Adverse reactions to first-line antituberculosis drugs. Expert Opin Drug Saf 2006, 5:231-249.

4. Marra F, Marra CA, Bruchet N, Richardson K, Moadebi S, Elwood RK, Fitzgerald $\mathrm{JM}$ : Adverse drug reactions associated with first-line anti-tuberculosis drug regimens. Int J Tuberc Lung Dis 2007, 11:868-875.

5. Saukkonen JJ, Cohn DL, Jasmer RM, Schenker S, Jereb JA, Nolan CM, Peloquin CA, Gordin FM, Nunes D, Strader DB, Bernardo J, Venkataramanan R, Sterling TR: An official ATS statement: hepatotoxicity of antituberculosis therapy. Am J Respir Crit Care Med 2006, 174:935-952.

6. Tostmann A, Boeree MJ, Aarnoutse RE, de Lange WC, van der Ven AJ, Dekhuijzen R: Antituberculosis drug-induced hepatotoxicity: concise up-to-date review. J Gastroenterol Hepatol 2008, 23:192-202.

7. Ohno M, Yamaguchi I, Yamamoto I, Fukuda T, Yokota S, Maekura R, Ito M, Yamamoto Y, Ogura T, Maeda K, Komuta K, Igarashi T, Azuma J: Slow $\mathrm{N}$-acetyltransferase 2 genotype affects the incidence of isoniazid and rifampicin-induced hepatotoxicity. Int J Tuberc Lung Dis 2000, 4:256-261.

8. Hussain Z, Kar P, Husain SA: Antituberculosis drug-induced hepatitis: risk factors, prevention and management. Indian J Exp Biol 2003, 41:1226-1232.

9. Huang YS, Chern HD, Su WJ, Wu JC, Chang SC, Chiang CH, Chang FY, Lee SD: Cytochrome P450 2E1 genotype and the susceptibility to antituberculosis drug-induced hepatitis. Hepatology 2003, 37:924-930.

10. Sharma SK, Balamurugan A, Saha PK, Pandey RM, Mehra NK: Evaluation of clinical and immunogenetic risk factors for the development of hepatotoxicity during antituberculosis treatment. Am J Respir Crit Care Med 2002, 166:916-919.

11. Shimizu Y, Dobashi K, Mita Y, Endou K, Moriya S, Osano K, Koike Y, Higuchi S, Yabe S, Utsugi M, Ishizuka T, Hisada T, Nakazawa T, Mori M: DNA microarray genotyping of $\mathrm{N}$-acetyltransferase 2 polymorphism using carbodiimide as the linker for assessment of isoniazid hepatotoxicity. Tuberculosis (Edinb) 2006, 86:374-381.

12. Mitchell JR, Zimmerman HJ, Ishak KG, Thorgeirsson UP, Timbrell JA, Snodgrass WR, Nelson SD: Isoniazid liver injury: clinical spectrum, pathology, and probable pathogenesis. Ann Intern Med 1976, 84:181-192

13. Farrell GC: Drug-induced acute hepatitis. In Drug-induced liver disease. Edited by Farrell G. Edinburgh Churchill Livingstone; 1994: 247-299

14. Ryan DE, Ramanathan L, lida S, Thomas PE, Haniu M, Shively JE, Lieber CS, Levin W: Characterization of a major form of rat hepatic microsomal cytochrome P-450 induced by isoniazid. J Biol Chem 1985, 260:6385-6393.

15. Mitchell JR, Thorgeirsson UP, Black M, Timbrell JA, Snodgrass WR, Potter WZ, Jollow HR, Keiser HR: Increased incidence of isoniazid hepatitis in rapid acetylators: possible relation to hydranize metabolites. Clin Pharmacol Ther 1975, 18:70-79.

16. Lauterburg BH, Smith CV, Todd EL, Mitchell JR: Pharmacokinetics of the toxic hydrazino metabolites formed from isoniazid in humans. J Pharmacol Exp Ther 1985, 235:566-570.

17. Fretland AJ, Leff MA, Doll MA, Hein DW: Functional characterization of human $\mathrm{N}$-acetyltransferase 2 (NAT2) single nucleotide polymorphisms. Pharmacogenetics 2001, 11:207-215.

18. Zang Y, Doll MA, Zhao S, States JC, Hein DW: Functional characterization of single-nucleotide polymorphisms and haplotypes of human N-acetyltransferase 2. Carcinogenesis 2007, 28:1665-1671.

19. Parkin DP, Vandenplas S, Botha FJ, Vandenplas ML, Seifart HI, van Helden PD, van der Walt BJ, Donald PR, van Jaarsveld PP: Trimodality of isoniazid elimination: phenotype and genotype in patients with tuberculosis. Am J Respir Crit Care Med 1997, 155:1717-1722.

20. Cascorbi I, Brockmoller J, Bauer S, Reum T, Roots I: NAT2*12A (803A->G) codes for rapid arylamine $n$-acetylation in humans. Pharmacogenetics 1996, 6:257-259.

21. Azuma J, Ohno M, Kubota R, Yokota S, Nagai T, Tsuyuguchi K, Okuda Y, Takashima T, Kamimura S, Fujio Y, Kawase I: NAT2 genotype guided regimen reduces isoniazid-induced liver injury and early treatment failure in the 6-month four-drug standard treatment of tuberculosis: a randomized controlled trial for pharmacogenetics-based therapy. Eur J Clin Pharmacol 2013, 69:1091-1101.

22. Kolble K: Regional mapping of short tandem repeats on human chromosome 10: cytochrome P450 gene CYP2E, D10S196, D10S220, and D10S225. Genomics 1993, 18:702-704.

23. Lucas D, Menez C, Girre C, Berthou F, Bodenez P, Joannet I, Hispard E, Bardou LG, Menez JF: Cytochrome P450 2E1 genotype and chlorzoxazone metabolism in healthy and alcoholic Caucasian subjects. Pharmacogenetics 1995, 5:298-304.

24. Neafsey P, Ginsberg G, Hattis D, Johns DO, Guyton KZ, Sonawane B: Genetic polymorphism in CYP2E1: Population distribution of CYP2E1 activity. J Toxicol Environ Health B Crit Rev 2009, 12:362-388.

25. Ait Moussa L, Khassouani CE, Hue B, Jana M, Begaud B, Soulaymani R: Determination of the acetylator phenotype in Moroccan tuberculosis patients using isoniazid as metabolic probe. Int J Clin Pharmacol Ther 2002, 40:548-553.

26. Garte S, Gaspari L, Alexandrie AK, Ambrosone C, Autrup H, Autrup JL, Baranova H, Bathum L, Benhamou S, Boffetta P, Bouchardy C, Breskyar K, Brockmoller J, Cascorbi I, Clapper ML, Coutelle C, Daly A, Dell'Omo M, Dolzan V, Dresler CM, Fryer A, Haugen A, Hein DW, Hildsheim A, Hirvonen A, Hsieh LL, Ingelman-Sundberg M, Kalina I, Kang D, Kihara M, et al: Metabolic gene polymorphism frequencies in control populations. Cancer Epidemiol Biomarkers Prev 2001, 10:1239-1248.

27. Sabbagh A, Langaney A, Darlu P, Gerard N, Krishnamoorthy R, Poloni ES: Worldwide distribution of NAT2 diversity: implications for NAT2 evolutionary history. BMC Genet 2008, 9:21.

28. Teixeira RL, Morato RG, Cabello PH, Muniz LM, Moreira Ada S, Kritski AL, Mello FC, Suffys PN, Miranda AB, Santos AR: Genetic polymorphisms of NAT2, CYP2E1 and GST enzymes and the occurrence of antituberculosis drug-induced hepatitis in Brazilian TB patients. Mem Inst Oswaldo Cruz 2011, 106:716-724.

29. Hamdy SI, Hiratsuka M, Narahara K, Endo N, El-Enany M, Moursi N, Ahmed MS, Mizugaki M: Genotype and allele frequencies of TPMT, NAT2, GST, 
SULT1A1 and MDR-1 in the Egyptian population. Br J Clin Pharmacol 2003, 55:560-569.

30. Chamorro JG, Castagnino JP, Musella RM, Frias A, Aranda FM, De Larranaga GF: The distribution of allelic and genotypic frequencies of N-Acetyltransferase-2 variants in an Argentine population. J Infect Dev Ctries 2012, 6:671-674.

31. Tanira MO, Simsek M, Al Balushi K, Al Lawatia K, Al Barawani H, Bayoumi RA: Distribution of arylamine $\mathrm{N}$-acetyltransferase 2 (nat2) genotypes among Omanis. J Sci Res Med Sci 2003, 5:9-14.

32. Bendjemana K, Abdennebi M, Gara S, Imal A, Ghanem A, Touati S, Boussen H, Ladgham A, Guemira F: Genetic polymorphism of gluthation-S transferases and $\mathrm{N}$-acetyl transferases 2 and nasopharyngeal carcinoma: the Tunisia experience. Bull Cancer 2006, 93:297-302.

33. Lin $\mathrm{HJ}$, Han CY, Lin BK, Hardy S: Ethnic distribution of slow acetylator mutations in the polymorphic N-acetyltransferase (NAT2) gene. Pharmacogenetics 1994, 4:125-134.

34. Kunak SC, Ada AO, Karacaoglan V, Soydas E, Bilgen S, Iscan M: Drug/ xenobiotic metabolizing enzyme polymorphisms in a Turkish population. African Journal of Pharmacy and Pharmacology 2012, 6(27):2068-2074.

35. Neuhaus T, Ko YD, Lorenzen K, Fronhoffs S, Harth V, Brode P, Vetter H, Bolt HM, Pesch B, Bruning T: Association of cytochrome P450 2E1 polymorphisms and head and neck squamous cell cancer. Toxicol Lett 2004, 151:273-282.

36. Brocic M, Supic G, Zeljic K, Jovic N, Kozomara R, Zagorac S, Zlatkovic M, Magic Z: Genetic polymorphisms of ADH1C and CYP2E1 and risk of oral squamous cell carcinoma. Otolaryngol Head Neck Surg 2011, 145:586-593.

37. Bouchardy C, Hirvonen A, Coutelle C, Ward PJ, Dayer P, Benhamou S: Role of alcohol dehydrogenase 3 and cytochrome P-4502E1 genotypes in susceptibility to cancers of the upper aerodigestive tract. Int $J$ Cancer 2000, 87:734-740.

38. Yang B, O'Reilly DA, Demaine AG, Kingsnorth AN: Study of polymorphisms in the CYP2E1 gene in patients with alcoholic pancreatitis. Alcohol 2001, 23:91-97.

39. Roy B, Ghosh SK, Sutradhar D, Sikdar N, Mazumder S, Barman S: Predisposition of antituberculosis drug induced hepatotoxicity by cytochrome P450 2E1 genotype and haplotype in pediatric patients. J Gastroenterol Hepatol 2006, 21:784-786.

40. Leiro-Fernandez V, Valverde D, Vazquez-Gallardo R, Constenla L, FernandezVillar A: Genetic variations of NAT2 and CYP2E1 and isoniazid hepatotoxicity in a diverse population. Pharmacogenomics 2010, 11:1205-1206. author reply 1207-1208.

41. Sefiani A: Genetic disorders in Morocco. In Genetic disorders Among Arab populations. Edited by Teebi A: Springer-Verlag Berlin Heidelberg; 2010: 455-472.

42. L C: Genetic Disorders in Tunisia. In Genetic Disorders Among Arab. 2nd edn. Edited by Teebi SA: Springer-Verlag Berlin Heidelberg; 2010: 613-638.

43. Sambrook JFE, Maniatis T: Molecular cloning: a laboratory manual. In Molecular Cloning: A Laboratory Manual. Edited by Sambrook J. New York: Cold Spring Harbor Laboratory Press; 1989.

\section{Submit your next manuscript to BioMed Central and take full advantage of:}

- Convenient online submission

- Thorough peer review

- No space constraints or color figure charges

- Immediate publication on acceptance

- Inclusion in PubMed, CAS, Scopus and Google Scholar

- Research which is freely available for redistribution 